\title{
Optimasi Produksi Bacterial Nanocellulose dengan Metode Kultur Agitasi
}

\author{
${ }^{1}$ Prima Besty Asthary*, ${ }^{1}$ Saepulloh, ${ }^{1}$ Ayu Sanningtyas, ${ }^{1}$ Gian Aditya Pertiwi, \\ ${ }^{1}$ Chandra Apriana Purwita, ${ }^{2}$ Krisna Septiningrum \\ ${ }^{1}$ Balai Besar Pulp dan Kertas, Jl. Raya Dayeuhkolot No 132 Bandung, Indonesia \\ ${ }^{2}$ Balai Besar Industri Agro, J1. Ir. H. Juanda No.11, Kota Bogor, Indonesia
}

Diterima : 7 Juli 2020, Revisi akhir : 24 Desember 2020, Disetujui terbit : 30 Desember 2020

\section{Optimization of Bacterial Nanocellulose Production in Agitation Culture Methods}

\begin{abstract}
Almost $90 \%$ of pharmaceutical industry in Indonesia still uses imported raw material. However, Indonesia has one of the abundant raw materials which is cellulose. Bacterial nanocellulose (BNC) is a pure form of nanocellulose biopolymer material synthesized by microbes such as acetic acid bacteria of Gluconacetobacter spp. as pure cellulose and having diameter in nano scale. BNC used in pharmaceutical industry is in the slurry form/high viscose nanocellulose. The purpose of this study is to determine the bacteria and the optimum conditions to produce BNC. The bacteria used were Gluconacetobacter xylinus and Gluconacetobacter intermedius from InaCC-LIPI and Gluconacetobacter sp. from nata industry. The inoculums were cultivated for 7 days in liquid Hestrin \& Schramm (HS) medium using static and agitation culture with a stirring speed of $150 \mathrm{rpm}$ at pH 5 and temperature $25{ }^{\circ} \mathrm{C}$. The production of BNC has been conducted by using Gluconacetobacter sp., because it has the highest yield. Then it was inoculated at different variation of agitation speed (100, 150, and $200 \mathrm{rpm}), \mathrm{pH}$ (4.0; 4.5; 5.0; and 6.0), and temperature $\left(25-30^{\circ} \mathrm{C}\right)$. This research shows that Gluconacetobacter sp. has optimum conditions at the agitation speed of $150 \mathrm{rpm}, \mathrm{pH} \mathrm{5.5}$, and temperature $27{ }^{\circ} \mathrm{C}$.
\end{abstract}

Keywords: Bacterial nanocellulose, Gluconacetobacter, agitation

\begin{abstract}
Abstrak
Hampir sebanyak 90\% industri farmasi di Indonesia masih menggunakan bahan baku impor. Indonesia memiliki salah satu bahan baku yang cukup melimpah yaitu selulosa. Bacterial nanocellulose (BNC) adalah hasil sintesis dari bakteri aerobic seperti bakteri asam asetat Gluconacetobacter spp. yang berbentuk selulosa murni dengan diameter berukuran nano. Bahan baku BNC yang digunakan dalam industri farmasi adalah BNC dalam bentuk slurry atau high viscose nanocellulose. Tujuan penelitian ini adalah untuk memilih bakteri dan kondisi optimum dalam memproduksi BNC. Bakteri yang digunakan adalah Gluconacetobacter xylinus dan Gluconacetobacter intermedius yang berasal dari InaCC-LIPI dan Gluconacetobacter sp. dari industri nata de coco. Inokulum dari ketiga jenis kultur bakteri tersebut dikultivasi selama 7 hari dalam medium Hestrin\&Schramm (HS) cair menggunakan kultur statis dan agitasi dengan kecepatan pengadukan $150 \mathrm{rpm}$ pada $\mathrm{pH} 5$ dan suhu $25^{\circ} \mathrm{C}$. Isolat bakteri Gluconacetobacter sp. dipilih sebagai bakteri penghasil BNC karena memiliki nilai yield paling tinggi. Kemudian isolat tersebut ditumbuhkan pada variasi kecepatan agitasi $(100,150$, dan $200 \mathrm{rpm})$, variasi $\mathrm{pH}(4,0 ; 4,5$; 5,0 ; dan 6,0), dan variasi suhu $\left(25-30^{\circ} \mathrm{C}\right)$. Penelitian ini menunjukkan bahwa Gluconacetobacter sp. memiliki kondisi optimum pada kecepatan agitasi $150 \mathrm{rpm}, \mathrm{pH} 5,5$, dan suhu $27^{\circ} \mathrm{C}$.
\end{abstract}

Kata kunci: Bacterial nanocellulose, Gluconacetobacter, agitasi 


\section{Pendahuluan}

Peningkatan pendapatan per kapita dan penggunaan obat pada masyarakat semakin menunjang pertumbuhan farmasi di Indonesia. Obat adalah komponen yang penting dalam memenuhi kesehatan masyarakat pada suatu negara. Semakin meningkatnya penggunaan obat tersebut menjadi salah satu faktor pertumbuhan pada industri farmasi. Pasar farmasi Indonesia saat ini mencapai $\pm 27 \%$ dari total pasar ASEAN, dengan nilai pasar mencapai Rp 69,07 triliun pada tahun 2016 dan Rp 102,05 triliun pada tahun 2020. Namun, sampai saat ini Indonesia masih memenuhi kebutuhan $90 \%$ bahan baku farmasi dalam negeri dengan melakukan impor dari negara Tiongkok (60\%), India (30\%), dan Eropa (10\%) (Simanjuntak, 2016).

Untuk mengurangi ketergantungan impor bahan obat tersebut perlu pengembangan lebih lanjut baik dalam bidang teknologi maupun bahan baku yang dapat digunakan. Indonesia mempunyai sumber daya berupa sumber daya manusia (SDM) dan keanekaragaman hayati yang dapat digunakan sebagai bahan baku serta potensi ekonomi yang besar. Salah satu sumber terbesar tersebut adalah biomassa berbasis selulosa, sehingga Indonesia perlu mengembangkan industri farmasi berbasis selulosa (Cellulose Based Pharmacy). Selulosa ini dapat digunakan sebagai sediaan produk biologik untuk industri farmasi. Salah satu contoh aplikasi tersebut adalah sebagai pembentuk hidrogel yang memiliki potensi untuk penutup luka (Gupta et al., 2020).

Sumber selulosa adalah tanaman dan bakteri (Bacterial cellulose, BC) (Jozala etal., 2014). BC adalah polisakarida ekstraselular (biomaterial berukuran nano) yang diproduksi oleh bakteri asam asetat dari genus seperti Acetobacter, Komagataeibacter, dan Gluconacetobacter (Gullo et al., 2017). Gluconacetobacter adalah bakteri Gram negatif, yang bersifat aerobik, berbentuk batang (M. Iguchi et al., 2000), non toksik dan merupakan bakteri yang paling efisien untuk menghasilkan selulosa (Shoda \& Sugano, 2005). Bakteri ini memproduksi pelikel BC yang memiliki struktur nanofibril dengan permukaan yang lebih padat di satu sisi, dan lapisan mirip gelatin di sisi lainnya (A.N. Nakagaito et al., 2005).

Bacterial nanocellulose (BNC) hasil sintesis dari bakteri aerobik seperti bakteri asam asetat yaitu Gluconacetobacter spp. yang berbentuk selulosa murni dengan diameter berukuran nano. BNC memiliki karakteristik yang unik jika dibandingkan dengan selulosa tanaman yaitu selulosa dari bakteri merupakan selulosa murni (Gatenholm \& Klemm, 2010) memiliki derajat polimerisasi yang tinggi yaitu mencapai 2000 sampai 6000 (Klemm et al., 2001), memiliki kapasitas menahan air yang tinggi dibandingkan dengan selulosa tanaman, karena memiliki ikatan hidrogen yang lebih kuat dan lebih banyak jika dibandingkan dengan selulosa tanaman (Watanabe et al., 1998), mempunyai kekuatan tarik yang baik (M. Iguchi et al., 2000; Nakagaito et al., 2005), memiliki bentuk kristal I $\alpha$ dan I $\beta$, tidak seperti selulosa tanaman yang terutama menyajikan struktur I $\beta$ (Atalla \& Vanderhart, 1984), non toksik, mudah dibiodegradasi dan tidak menyebabkan alergi (Jozala et al., 2016), memiliki diameter serat $20-200 \mathrm{~nm}$ dengan luas permukaan yang besar (Fu et al., 2013; Numata et al., 2015) sehingga mampu menyerap air dalam jumlah besar, dan memiliki adherence yang baik (Fu et al., 2013; Numata et al., 2015).

Berdasarkan karakteristik tersebut BNC dapat digunakan pada berbagai macam jenis industri seperti industri tekstil, industri kertas, industri farmasi, dll. Industri farmasi menggunakan bahan baku BNC dalam bentuk slurry. Penelitian dalam memproduksi BNC bentuk slurry dengan produktivitas yang baik diharapkan dapat memberikan kontribusi terhadap kemajuan penelitian BNC di masa depan terutama aplikasi BNC di bidang nanoteknologi. Tujuan dari penelitian ini adalah untuk memilih bakteri penghasil BNC dan memperoleh kondisi optimum produksi BNC skala laboratorium.

\section{Bahan dan Metode}

\section{Bahan}

Bahan-bahan penelitian yang digunakan adalah tiga jenis kultur bakteri yaitu dua kultur bakteri murni dari InaCCLIPI Gluconacetobacter xylinus dan Gluconacetobacter intermedius dan satu kultur bakteri berasal dari industri nata de coco di Jawa Barat; medium Hestrin\&Schramm (HS) yang terdiri dari glukosa, pepton, ekstrak ragi, $\mathrm{Na}_{2} \mathrm{HPO}_{4}$, dan $\mathrm{C}_{6} \mathrm{H}_{8} \mathrm{O}_{7} \cdot \mathrm{H}_{2} \mathrm{O}$; agar; akuades; etanol teknis; $\mathrm{NaCl}$; spiritus; dan bahan kimia untuk melakukan uji Total Plate Count (TPC), uji 
karbon organik, dan uji total nitrogen. Peralatan penelitian yang digunakan adalah cawan petri, labu Erlenmeyer, gelas ukur, mikropipet, tips, blender, autoklaf, shaker incubator, incubator, microcentrifuge, waterbath, penangas air, $\mathrm{pH}$ meter, spektrofotometer VIS, magnetic stirrer, neraca analitis dan semi analitis, vortex mixer, refrigerated centrifuge, dan laminar air flow.

\section{Skrining Bakteri Penghasil BNC}

Penentuan bakteri penghasil BNC dilakukan dengan memurnikan terlebih dahulu kultur yang berasal dari industri nata de coco (JUM), kemudian diidentifikasi secara molekuler berdasarkan analisis genetika secara parsial pada $16 \mathrm{~S}$ rDNA. Inokulum dari ketiga jenis kultur bakteri dikultivasi selama 7 hari dalam medium HS cair menggunakan kultur statis dan agitasi dengan kecepatan pengadukan 150 rpm pada pH 5 dan suhu ruang $\left(25^{\circ} \mathrm{C}\right)$ untuk menghasilkan BNC. BNC yang diperoleh dihitung berat basah dan berat kering yang dinyatakan dengan satuan $\mathrm{g} / \mathrm{L}$.

Setelah diketahui nilai yield dari ketiga jenis bakteri tersebut dipilih bakteri yang menghasilkan nilai yield tertinggi, lalu $\mathrm{BNC}$ yang diperoleh dari inokulum bakteri terpilih tersebut dilakukan analisis karakterisasi BNC. Analisis karakteristik BNC dilakukan dengan melakukan pengujian menggunakan Scanning Electrom Miroscopy (SEM) JEO KSM 6510 untuk mengetahui formasi permukaan BNC, $X$-ray difraction (XRD) Rigaku SmartLab untuk mengatahui pengaruh pengadukan terhadap struktur kristal selulosa, Fourier Transform Infra Red (FTIR) 4200TypeA untuk mengetahui gugus fungsional BC (Bacterial Cellulose), dan particle size analyzer HORIBA LB-550 untuk mengetahui ukuran partikel.

\section{Penentuan Kondisi Optimum dan Kecepatan Agitasi Produk BNC}

Inokulum mikroba sejumlah $1-4 \quad \%(\mathrm{v} / \mathrm{v})$ dengan konsentrasi $10^{6} \mathrm{CFU} / \mathrm{mL}$ diinokulasikan ke dalam medium HS Kultur kemudian diinkubasi selama 7 hari pada variasi kecepatan agitasi $(100,150$, dan $200 \mathrm{rpm})$, variasi $\mathrm{pH}(4,0$; $4,5 ; 5,0 ;$ dan 6,0$)$, dan variasi suhu $\left(25-30{ }^{\circ} \mathrm{C}\right)$. Kultur disampling setelah 7 hari. Parameter uji pada proses fermentasi adalah rendemen BNC yang diperoleh dan $\mathrm{pH}$.

\section{Hasil dan Pembahasan}

\section{Penentuan Isolat Bakteri Penghasil BNC}

Hasil identifikasi kultur JUM yang dilakukan secara molekuler berdasarkan analisis genetika secara parsial pada $16 \mathrm{~S}$ rDNAmenunjukkan isolat bakteri berasal dari genus Acetobacter sp. PA2.2 (Gluconacetobacter sp.) dengan nomor accession AF062474.2. Selulosa dapat dihasilkan oleh bakteri, terutama dari genus Gluconacetobacter. Berbagai spesies dari genus Gluconacetobacter mampu menghasilkan bacterial cellulose, salah satunya adalah Gluconacetobacter xylinus (dulu dikenal dengan Acetobacter xylinus) yang merupakan spesies yang paling banyak digunakan secara komersial (Kost et al., 1998; Tanskul et al., 2013).

Berat kering dan berat basah selulosa yang dihasilkan oleh ketiga jenis isolat bakteri Gluconacetobacter dengan metode kultur agitasi dan statis disajikan pada Gambar 1. Isolat bakteri yang mampu menghasilkan selulosa dengan kedua metode kultur tersebut adalah kultur yang diperoleh dari industri nata de coco (JUM) dan Gluconacetobacter xylinus (B420) yang diperoleh dari InaCC-LIPI. Sementara itu, isolat JUM mampu menghasilkan selulosa dengan berat basah dan berat kering paling tinggi di antara seluruh isolat bakteri, yaitu sebesar 32,143 $\mathrm{mg} / \mathrm{mL}$ dan $0,6 \mathrm{mg} / \mathrm{mL}$ untuk metode agitasi dan $21,314 \mathrm{mg} / \mathrm{mL}$ dan $0,013 \mathrm{mg} / \mathrm{mL}$ untuk metode statis. Metode agitasi mampu menghasilkan selulosa dengan berat basah dan berat kering lebih tinggi dibandingkan metode statis. Tujuan dilakukannya agitasi adalah menjaga pasokan

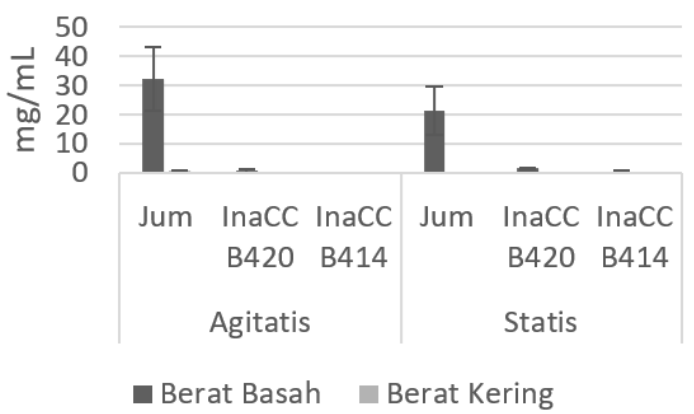

Gambar 1. Berat Basah dan Berat Kering Selulosa dari Proses Fermentasi oleh Isolat JUM, InaCC B414 dan InaCC B420 dengan Metode Kultur Agitasi dan Statis 
dan distribusi oksigen dapat tetap homogen dibanding dengan kondisi statis yang dilakukan tanpa putaran. Menurut Hwang et al., (1999) laju produksi dan yield pada selulosa sebanding dengan laju transfer oksigen dan koefisien transfer oksigen. Hal tersebut menunjukkan bahwa konsentrasi oksigen terlarut yang ada di dalam sel pada matrik selulosa merupakan faktor penting dalam penentuan kenaikan yield (Joseph et al., 2003).

Selulosa yang dihasilkan oleh isolat JUM baik metode agitasi maupun metode statis memiliki morfologi serat seperti yang ditampilkan pada Gambar 2. Serat selulosa yang dihasilkan pada kedua metode memiliki rentang diameter hingga $200 \mathrm{~nm}$. Namun, serat selulosa metode agitasi memiliki diameter cenderung lebih besar 56\% dibandingkan dengan metode statis. Menurut (Fu et al., 2013) bacterial cellulose mengandung serat berukuran nano dengan kisaran 20-100 nm. Hasil analisis crystallinity BNC ditampilkan pada Gambar 3 menunjukkan bahwa BNC yang dihasilkan oleh isolat JUM dengan kultur agitasi

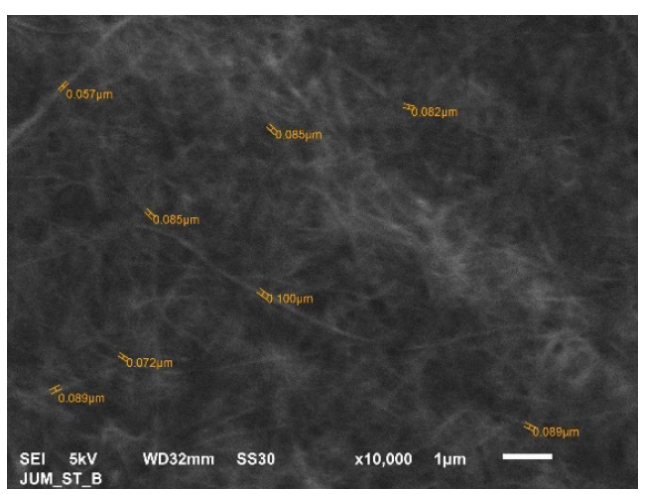

(a)

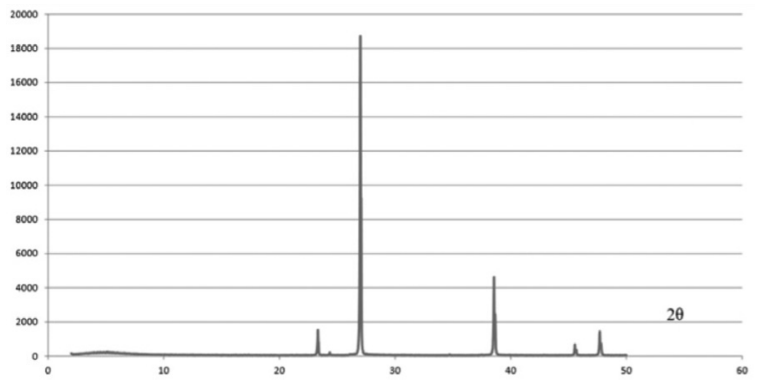

Gambar 3. Hasil Analisa Crystallinity BNC dari Isolat Terpilih (JUM) dengan Kultur Agitasi

adalah kristalin dengan puncak pada sudut difraksi $2 \theta$ : 23,$33 ; 27,18 ; 38,56 ; 45,54$; dan 47,69 .

Karakterisasi struktur molekuler (gugus fungsi) pada sampel bacterial nanocellulose hasil penelitian dilakukan dengan analisis secara spektrofotometri menggunakan FTIR pada rentang bilangan gelombang 4000-400 $\mathrm{cm}^{-1}$ dengan resolusi $16 \mathrm{~cm}^{-1}$. Berdasarkan spektrum FTIR dari sampel bacterial cellulose seperti yang ditunjukkan pada Gambar 4 terdapat pita

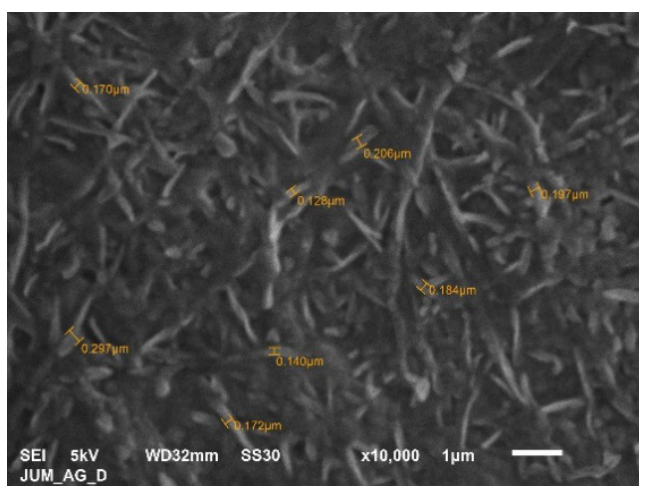

(b)

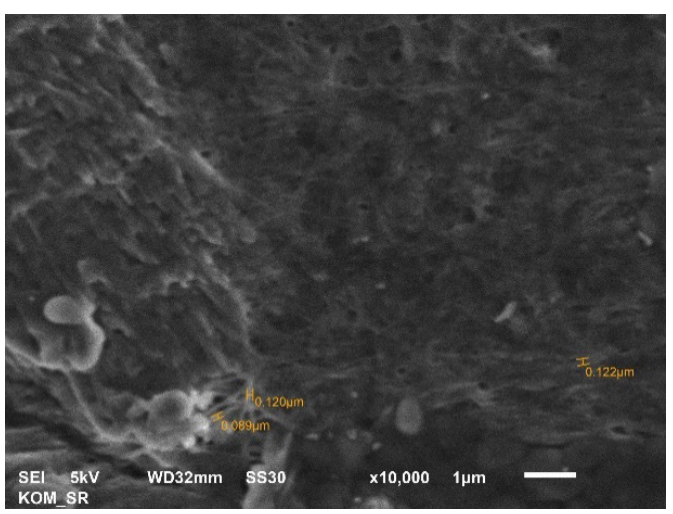

(c)

Gambar 2. Morfologi Bacterial Nanocellulose yang dihasilkan oleh Isolat Terpilih (JUM) dari Kultur Statis (a), dan Kultur Agitasi (b), dan Bacterial Nanocellulose Komersial Sebagai Pembanding (c) 

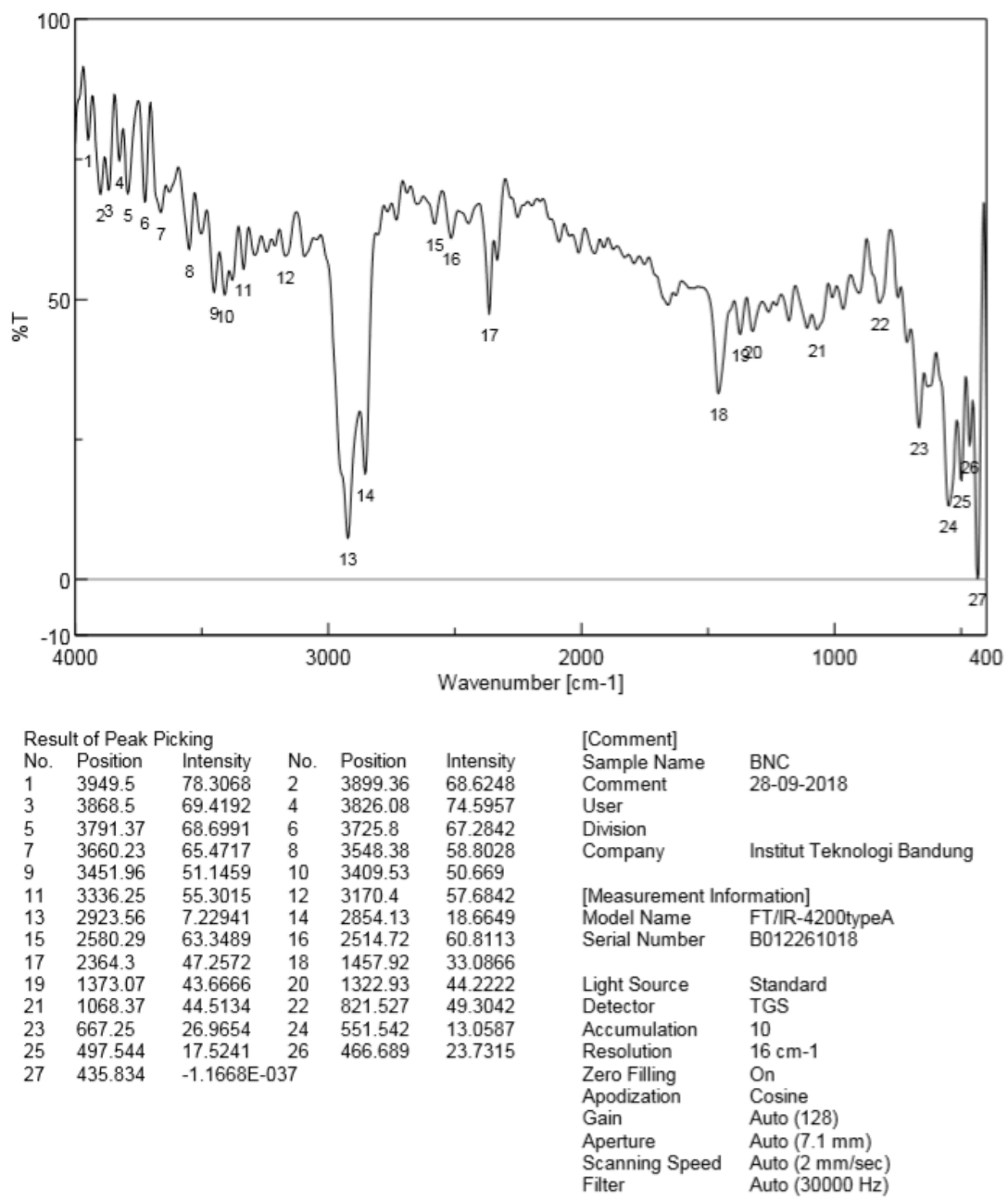

Gambar 4. Hasil Analisis Gugus Fungsional BNC dengan Menggunakan FTIR

transmitant pada beberapa bilangan gelombang yang menjadi ciri khas dari bacterial cellulose, yaitu pita transmitant pada bilangan gelombang $3726,3452,3410,2923,2854,2364,1458$, 1373, 1323, dan $1066 \mathrm{~cm}^{-1}$. Transmitant pada bilangan gelombang $3600-3000 \mathrm{~cm}^{-1}$ pada spektrum FTIR bacterial cellulose merupakan serapan karena renggangan dari gugus hidroksil $(-\mathrm{OH})$ yang terlibat dalam ikatan hidrogen baik antar gugus-gugus hidroksi yang ada dalam satu molekul bacterial cellulose (intramolekuler) maupun antara gugus hidroksil dari satu molekul bacterial cellulose dengan gugus hidroksil pada molekul bacterial cellulose lainnya atau dengan molekul lainnya yang dapat membentuk ikatan hidrogen seperti molekul air (inter molekuler) (Dima et al., 2017; Mohammadkazemi, 2015; Yue et al., 2015). Pada umumnya, spektrum FTIR pada bilangan gelombang $3600-3000 \mathrm{~cm}^{-1}$ dari selulosa atau bacterial cellulose yang masih basah berupa lembah yang lebar dengan intensitas yang rendah (serapan dengan intensitas tinggi) yang menunjukkannya banyaknya ikatan hidrogen baik inter maupun intra molekuler (Gayathry \& Gopalaswamy, 2014). Hal itu berbeda dengan spektrum FTIR sampel bacterial cellulose dimana pada bilangan gelombang $3600-3000 \mathrm{~cm}^{-1}$ pita transmitant berupa lembah yang tidak melebar dengan intensitas transmitant yang tinggi (serapan dengan intensitas rendah). Hal ini diperkirakan karena sampel bacterial cellulose sudah dikeringkan sehingga ikatan hidrogen yang terbentuk terutama ikatan hidrogen intermolekuler antara gugus hidroksil bacterial cellulose dengan molekul air menjadi berkurang. Hal itu juga didukung dengan tingginya nilai persen transmitant (rendahnya nilai serapan) pada bilangan gelombang $3726 \mathrm{~cm}^{-1}$ yang menunjukkan sedikitnya serapan oleh gugus hidroksil bebas (-OH) dari molekul air (Pavaloiu et al., 2014). Pita transmitant pada bilangan gelombang 2923 dan $2854 \mathrm{~cm}^{-1}$ menunjukan regangan $-\mathrm{CH}_{2}$ 
(Dima et al., 2017; Gayathry \& Gopalaswamy, 2014; Mohammadkazemi, 2015). Pada spektrum FTIR sampel bacterial cellulose, pita transmitant pada bilangan gelombang 2923 dan $2854 \mathrm{~cm}^{-1}$ berupa lembah tajam dengan transmitant rendah yang menunjukkan tinggi serapan pada bilangan gelombang tersebut karena banyaknya gugus $-\mathrm{CH}_{2}$. Pada penelitian yang telah dilakukan oleh Dima et al., (2017) hal tersebut diperkirakan karena terjadinya pembentukan ujung rantai baru akibat pemendekan fibril-fibril selulosa. Pita transmitant pada bilangan gelombang $1458 \mathrm{~cm}^{-1}$ menunjukan adanya serapan karena tekukan $\mathrm{C}-\mathrm{H}$ atau gugus karbonil (Gayathry \& Gopalaswamy, 2014; Mohammadkazemi, 2015). Pita transmitant

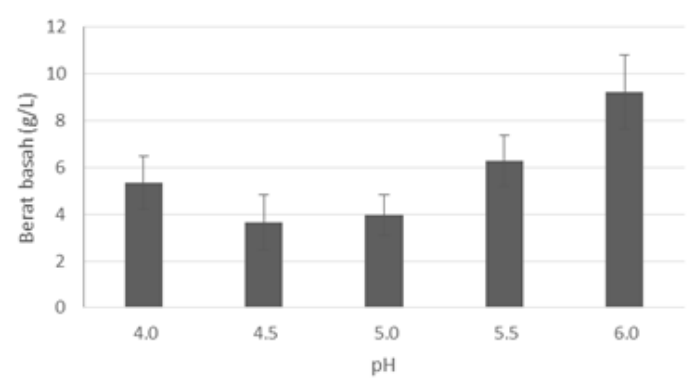

(a)

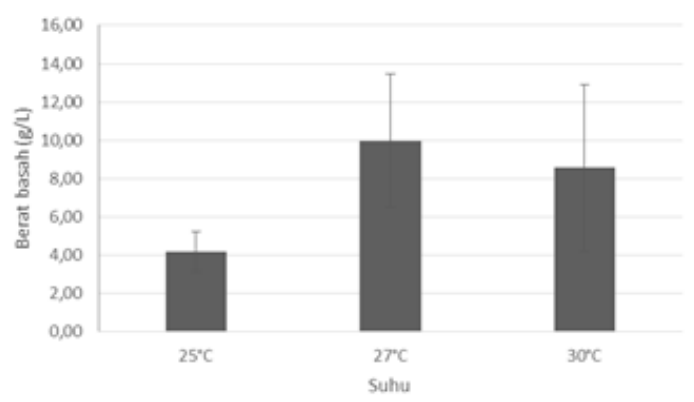

(c)

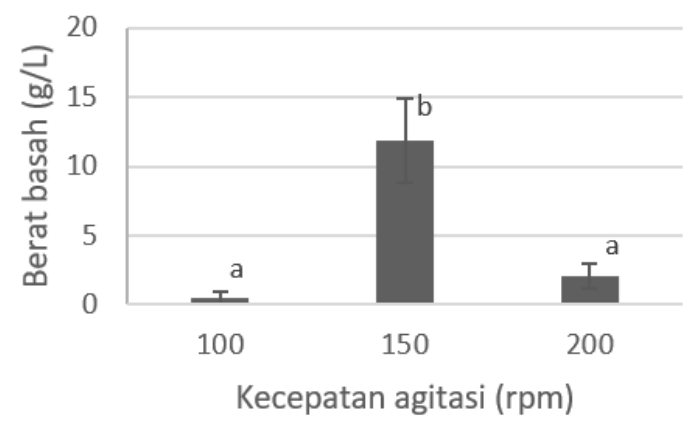

(e) pada $1373 \mathrm{~cm}^{-1}$ menunjukkan serapan karena deformasi gugus $-\mathrm{CH}$, sedangkan pita transmitant pada $1323 \mathrm{~cm}^{-1}$ menunjukkan serapan karena deformasi gugus -OH (Dima et al., 2017; Pandey, 1999). Pita transmitant pada bilangan gelombang $1066 \mathrm{~cm}^{-1}$ menunjukan serapan karena adanya renggangan gugus $\mathrm{C}-\mathrm{O}-\mathrm{C}$ pada rantai utama bacterial cellulose (Dima et al., 2017; Gayathry \& Gopalaswamy, 2014; Mohammadkazemi, 2015).

\section{Penentuan Kondisi Optimum Produksi BNC}

Pada percobaan optimasi $\mathrm{pH}$, nilai rata-rata berat basah dan berat kering BNC dapat dilihat pada Gambar 5a dan Gambar 5b. Yield BNC

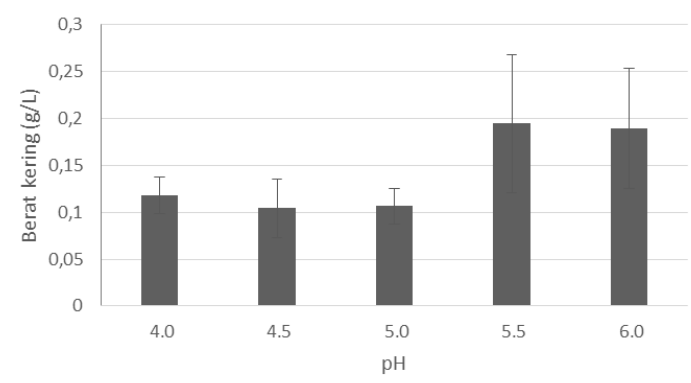

(b)

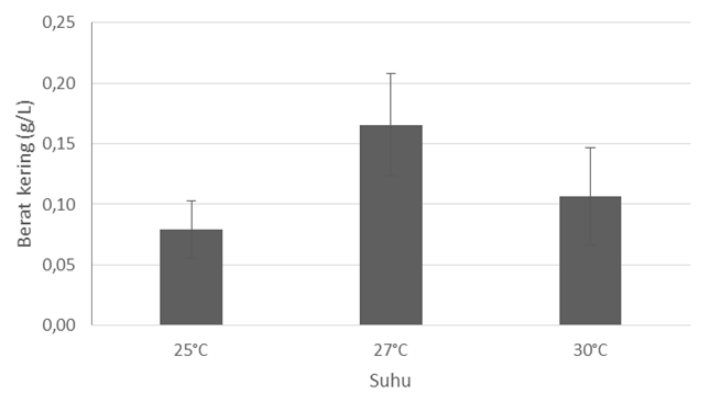

(d)

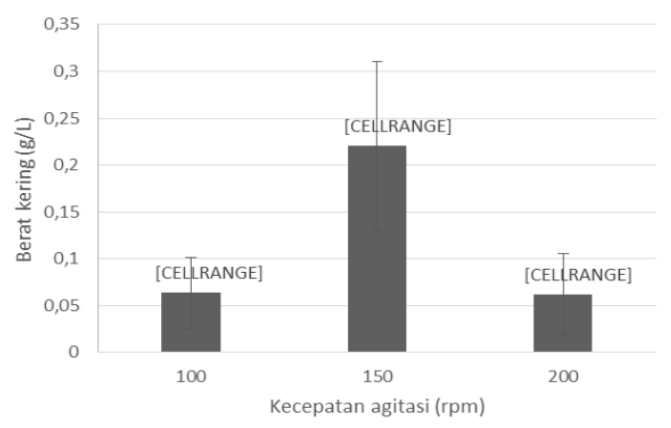

(f)

Gambar 5. Nilai Rata-Rata Berat Basah (a) dan Berat kering (b) Produk BNC pada Variasi pH 4,0-6,0, Nilai Rata-Rata Berat Basah (c) dan Berat Kering (d) Produk BNC pada Variasi Suhu $25-30{ }^{\circ} \mathrm{C}$, dan Nilai Rata-rata Berat Basah (e) dan Berat Kering (f) Produk BNC pada Variasi Kecepatan Agitasi 
Tabel 1. Hasil Analisis Statistik Berat Basah dan Berat Kering Produk BNC pada Variasi $\mathrm{pH}$ $4,0-6,0$

\begin{tabular}{ccc}
\hline $\mathrm{pH}$ & Berat Basah $(\mathrm{g} / \mathrm{L})$ & Berat Kering $(\mathrm{g} / \mathrm{L})$ \\
\hline 4,0 & $5,33820 \mathrm{bc}$ & $0,11780 \mathrm{a}$ \\
4,5 & $3,65060 \mathrm{a}$ & $0,10420 \mathrm{a}$ \\
5,0 & $3,98240 \mathrm{ab}$ & $0,10680 \mathrm{a}$ \\
5,5 & $6,29260 \mathrm{c}$ & $0,19460 \mathrm{~b}$ \\
6,0 & $9,23920 \mathrm{~d}$ & $0,18920 \mathrm{~b}$ \\
\hline
\end{tabular}

Keterangan: Angka dengan huruf yang sama pada kolom yang sama menunjukkan nilai yang tidak berbeda nyata pada taraf $5 \%$

terendah dihasilkan pada $\mathrm{pH}$ 4,5, kemudian mengalami peningkatan hingga $\mathrm{pH} 5,5$, kemudian mengalami penurunan pada $\mathrm{pH}$ 6,0. Berdasarkan hasil analisis statistik (Tabel 1), hasil BNC berbeda nyata pada $\mathrm{pH} 5,5$ dan 6,0 . Berat basah BNC paling tinggi $(9,24 \mathrm{~g} / \mathrm{L})$ dihasilkan pada $\mathrm{pH} 6,0$, sedangkan berat kering BNC paling tinggi $(0,19 \mathrm{~g} / \mathrm{L})$ dihasilkan pada $\mathrm{pH} 5,5$.

$\mathrm{pH}$ menggambarkan konsentrasi ion hidrogen di media tumbuh mikroorganisme tersebut. Konsentrasi ion hidrogen mempengaruhi kemampuan mikroorganisme dalam mensistesis enzim yang dibutuhkan untuk metabolisme. Pertumbuhan mikroorganisme paling baik adalah pada kondisi $\mathrm{pH}$ optimal. Pada umumnya selulosa dihasilkan oleh bakteri pada kondisi $\mathrm{pH}$ netral mendekati asam. Setiap strain bakteri penghasil selulosa memiliki $\mathrm{pH}$ optimal yang berbeda (Benson 2001; Castro et al. 2012). Castro et al., (2012) memproduksi bacterial cellulose dari Gluconacetobacter medellensis yang optimal pada $\mathrm{pH}$ 3,5 sehingga bakteri tersebut dikategorikan sebagai strain baru Gluconacetobacter tahan asam. Sedangkan beberapa penelitian menunjukan Acetobacter xylinum memiliki pH optimal pada $\mathrm{pH}$ 5,0 (Zahan et al., 2015) dan pH 6,5 (Coban \& Biyik, 2011).

Penelitian ini menggunakan sumber karbon berupa glukosa sehingga interaksi antara glukosa dengan $\mathrm{pH}$ 5,5 dan 6,0 menghasilkan BNC dengan jumlah yang lebih tinggi dibandingkan dengan $\mathrm{pH}$ lainnya. $\mathrm{pH}$ optimum yang dibutuhkan oleh tiap strain bakteri untuk menghasilkan selulosa berbeda-beda. Interaksi antara jenis sumber karbon dan $\mathrm{pH}$ juga mempengaruhi produksi selulosa. Hutchens et al., (2008) menyatakan bahwa $\mathrm{pH}$ sendiri tidak mempengaruhi produksi selulosa secara signifikan, tetapi produksi bakteri dipengaruhi oleh interaksi antara $\mathrm{pH}$ dan sumber
karbon.Interaksiglukosa dan pH6,5 menghasilkan selulosa yang lebih tinggi dibandingkan $\mathrm{pH}$ 5,5. Berdasarkan hasil percobaan, $\mathrm{pH}$ 5,5 dipilih sebagai $\mathrm{pH}$ optimal produksi $\mathrm{BNC}$ dengan isolat JUM. Selain berat kering produk BNC yang dihasilkan paling tinggi, pertimbangan lainnya adalah biaya medium produksi. Pada dasarnya medium HS memiliki pH awal dengan kisaran 5,0. Untuk meningkatkan $\mathrm{pH}$ medium HS memerlukan larutan basa yaitu $\mathrm{NaOH}$. Jika $\mathrm{pH}$ yang diinginkan semakin tinggi maka semakin banyak bahan kimia yang digunakan. Hal ini akan berdampak pada peningkatan biaya untuk medium produksi BNC.

Gambar 6a menampilkan $\mathrm{pH}$ medium awal, setelah penambahan inokulum, dan setelah inkubasi selama 7 hari pada percobaan dengan variasi $\mathrm{pH}$. Pada medium dengan sumber karbon glukosa, sintesis selulosa akan bersaing dengan peristiwa oksidasi glukosa oleh glukosa dehidrogenase yang ada di membran sel. Oksidasi glukosa menghasilkan asam ketoglukonat sebagai produk samping. Asam ketoglukonat yang dilepaskan ke medium menyebabkan penurunan $\mathrm{pH}$ medium selama kultivasi (Vandamme et al., 1998) sampai pada kisaran pH 3 di akhir kultivasi. Pada medium dengan $\mathrm{pH}$ awal 4 dan 4,5 mengalami penurunan $\mathrm{pH}$ hingga mencapai 3,0 di akhir kultivasi. Medium dengan $\mathrm{pH}$ awal 5,0; 5,5; dan 6,0 mengalami penurunan hingga masing-masing mencapai $\mathrm{pH}$ 3,1; 3,2; dan 3,3 di akhir kultivasi. Penurunan $\mathrm{pH}$ kemungkinan dapat menghambat produksi selulosa. Penggunaan medium dengan $\mathrm{pH}$ awal yang lebih basa dapat mengurangi penurunan $\mathrm{pH}$ sehingga meningkatkan produksi BNC. Karena A. xylinum adalah bakteri asidofilik tetapi jika berada pada lingkungan yang terlalu asam $(<\mathrm{pH} 4,0)$ dapat menghambat pertumbuhan bakteri sehingga produksi $\mathrm{BC}$ semakin turun (Hwang et al., 1999). Sehingga $\mathrm{pH}$ media pada kisaran $\mathrm{pH} 5,0$ perlu dipertahankan dalam meningkatkan produksi selulosa bakteri dan meningkatkan pertumbuhan $A$. xylinum pada saat fermentasi (Zahan et al., 2015). Penelitian yang dilakukan oleh Chen et al., (2019) menunjukkan bahwa dengan menggunakan medium yang memiliki nilai awal $\mathrm{pH}$ yang rendah $(\mathrm{pH} 4,5$ dibandingkan $\mathrm{pH}$ 6) dapat meningkatkan yield dan produktivitas BNC.

Penentuan suhu optimum dilakukan dengan menumbuhkan isolat terpilih (JUM) dalam medium HS dengan tiga variasi suhu $(25,27$, dan 


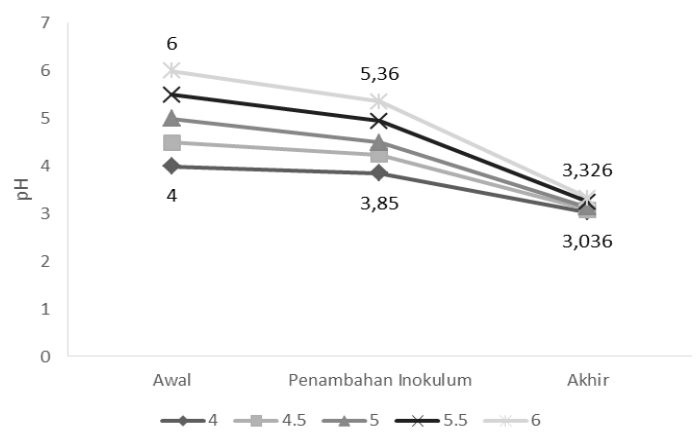

(a)

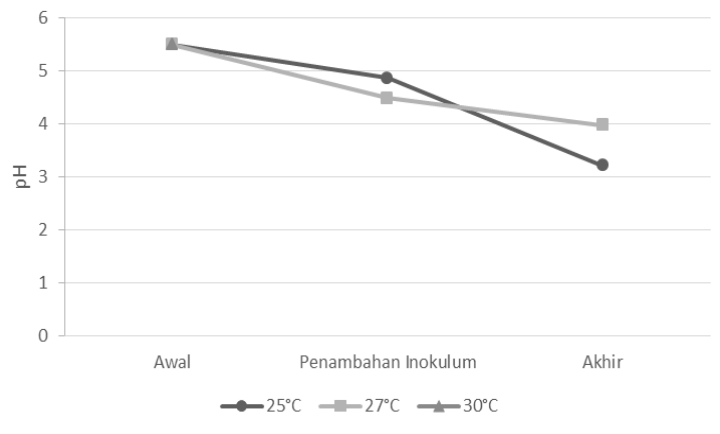

(b)

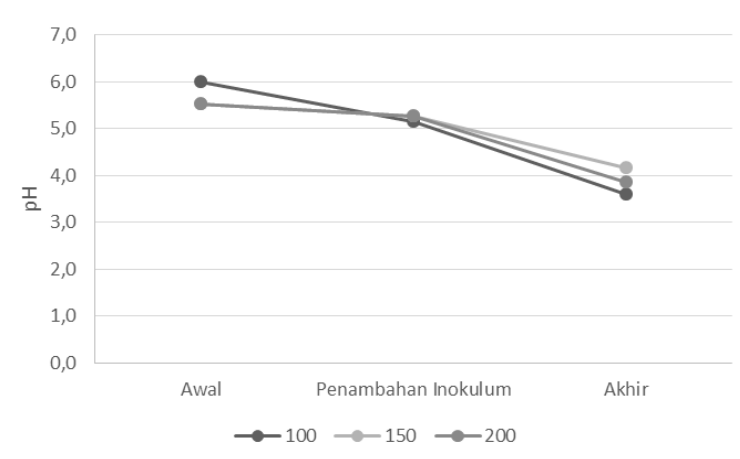

(c)

Gambar 6. pH Kultur Produksi BNC pada Percobaan Variasi pH (a), Variasi Suhu $25-30{ }^{\circ} \mathrm{C}$ (b), dan Variasi Kecepatan Agitasi (c)

$30^{\circ} \mathrm{C}$ ) dengan yield $\mathrm{BNC}$ disajikan pada Gambar 5c dan Gambar 5d. Produk BNC dengan berat basah dan berat kering paling rendah dihasilkan pada suhu $25{ }^{\circ} \mathrm{C}$, yaitu sebesar $3,95 \mathrm{~g} / \mathrm{L}$ dan $0,0744 \mathrm{~g} / \mathrm{L}$. Pada suhu $30^{\circ} \mathrm{C}$ BNC yang dihasilkan lebih tinggi dibandingkan dengan produk $\mathrm{BNC}$ pada suhu $25{ }^{\circ} \mathrm{C}$ dengan berat basah dan berat kering sebesar 8,5534 g/L dan 0,1066 g/L. Produksi BNC tertinggi dicapai pada suhu $27^{\circ} \mathrm{C}$ dengan berat basah dan berat kering sebesar $9,9760 \mathrm{~g} / \mathrm{L}$ dan $0,1658 \mathrm{~g} / \mathrm{L}$ secara berurutan.

Suhu memiliki peranan yang penting dalam pertumbuhan bakteri. Enzim yang digunakan untuk metabolisme bakteri sangat dipengaruhi oleh suhu lingkungan. Gluconacetobacter penghasil selulosa termasuk jenis bakteri mesofil yang hidup pada rentang suhu $10-47{ }^{\circ} \mathrm{C}$ (Benson, 2001). Variasi suhu yang digunakan untuk produksi BNC isolat terpilih JUM (25, 27 , dan $30^{\circ} \mathrm{C}$ ) termasuk dalam rentang suhu optimal produksi selulosa. Produksi selulosa oleh Gluconacetobacter dilaporkan optimum pada kisaran suhu $25-30{ }^{\circ} \mathrm{C}$ dan tidak ada perbedaan signifikan antara kedua suhu tersebut (Mohite et al., 2013). Namun, hasil analisis statistik produk BNC pada Tabel 2 menunjukkan hasil yang tidak sejalan dengan pernyataan tersebut. Berat basah BNC pada suhu $27^{\circ} \mathrm{C}$ dan $30^{\circ} \mathrm{C}$ berbeda signifikan dengan berat basah BNC pada suhu $25^{\circ} \mathrm{C}$, sedangkan untuk berat kering $\mathrm{BNC}$, suhu $27{ }^{\circ} \mathrm{C}$ menunjukkan perbedaan yang signifikan dibandingkan dengan perlakuan lainnya. Son et al., (2001) melaporkan hasil produksi selulosa Acetobacter xylinum pada berbagai variasi suhu kisaran 20-40 ${ }^{\circ} \mathrm{C}$. Produksi selulosa meningkat seiring kenaikan suhu dan mulai menurun pada suhu $35^{\circ} \mathrm{C}$. Kenaikan suhu meningkatkan kecepatan reaksi kimia dalam sel bakteri sehingga bakteri tumbuh lebih cepat. Pada penelitian ini, produksi BNC mengalami peningkatan hingga suhu $27^{\circ} \mathrm{C}$

Tabel 2. Hasil Analisis Statistik Yield BNC pada Variasi Suhu $25-30{ }^{\circ} \mathrm{C}$

\begin{tabular}{lcc}
\hline Suhu & Berat Basah $(\mathrm{g} / \mathrm{L})$ & Berat Kering $(\mathrm{g} / \mathrm{L})$ \\
\hline 25 & $3,9500 \mathrm{a}$ & $0,0744 \mathrm{a}$ \\
27 & $9,9760 \mathrm{~b}$ & $0,1658 \mathrm{~b}$ \\
30 & $8,5534 \mathrm{~b}$ & $0,1066 \mathrm{a}$ \\
\hline
\end{tabular}

Keterangan : Angka dengan huruf yang sama pada kolom yang sama menunjukkan nilai yang tidak berbeda nyata pada taraf $5 \%$ 
dimana dapat dikatakan suhu $27{ }^{\circ} \mathrm{C}$ merupakan suhu optimal bagi isolat JUM untuk tumbuh dan menghasilkan selulosa.

Gambar 6b menampilkan $\mathrm{pH}$ medium awal, setelah penambahan inokulum, dan setelah inkubasi selama 7 hari pada percobaan penentuan suhu optimum. Dapat terlihat bahwa $\mathrm{pH}$ pada tiap perlakuan mengalami penurunan hingga akhir inkubasi dan berakhir pada kisaran $\mathrm{pH}$ 3,2-3,9. Fenomena ini sesuai dengan percobaan penentuan pH optimum yang dilakukan sebelumnya.

Gambar 5e dan Gambar 5f menyajikan berat basah dan berat kering BNC yang dihasilkan dengan variasi kecepatan agitasi 100, 150, dan $200 \mathrm{rpm}$. Dapat terlihat bahwa produk BNC yang dihasilkan pada kecepatan agitasi $150 \mathrm{rpm}$ memiliki berat basah dan berat kering paling tinggi di antara semua perlakuan, yaitu sebesar 11,8378 dan 0,2204 g/L. Hasil analisis statistik menunjukkan bahwa perlakuan 150 rpm berbeda nyata dengan perlakuan lainnya. Dapat disimpulkan bahwa kecepatan agitasi optimal untuk produksi BNC dengan isolat JUM adalah $150 \mathrm{rpm}$. Sesuai dengan penelitian yang dilakukan oleh Zywicka et al., (2015) bahwa kecepatan pengadukan selama kultivasi adalah salah satu parameter penting yang mempengaruhi kuantitas dan kualitas $\mathrm{BC}$ yang disintesis. Pada penelitian yang dilakukan oleh Zywicka et al., (2015) berat BC tertinggi pun diperoleh pada kecepatan agitasi $150 \mathrm{rpm}$.

Gambar 6c menunjukkan $\mathrm{pH}$ medium awal, setelah penambahan inokulum, dan kultur setelah inkubasi selama 7 hari. Terjadi penurunan $\mathrm{pH}$ setelah penambahan inokulum. Setelah inkubasi selama 7 hari, $\mathrm{pH}$ kultur pada semua perlakuan kecepatan agitasi mengalami penurunan hingga kisaran pH 3,5-4,2. Menurut Jozala et al., (2014), $\mathrm{pH}$ akhir medium setelah fermentasi cenderung asam, yaitu berkisar antara 3,5-5. Menurut (Kouda et al., 1997) pertumbuhan Gluconacetobacter dipengaruhi oleh suplai oksigen yang dipengaruhi oleh konfigurasi agitator, termasuk parameter level pencampuran, kecepatan, dan kekuatan agitasi.

Oksigen adalah salah satu faktor penting dalam menghasilkan selulosa. Kondisi agitasi meningkatkan luas permukaan dengan udara dan media dan juga meningkatkan produksi selulosa (Mohite et al., 2013). Tetapi pada kecepatan $200 \mathrm{rpm}$ nilai yield yang didapat menjadi turun. Pa'e et al. (2011) menyatakan bahwa konsentrasi oksigen terlarut semakin meningkat seiring dengan meningkatnya kecepatan perputaran rotasi tetapi semakin cepat perputaran rotasi akan menurunkan produksi selulosa karena kultur semakin tidak stabil. Semakin tinggi kecepatan agitasi semakin kecil pula ukuran partikel selulosa yang terbentuk (Hu \& Catchmark, 2010).

Produksi BC yang efektif dan efisien menggunakan kultur agitasi terus berkembang. Hal ini disebabkan strain bakteri dan kondisi kultur fermentasi yang digunakan dapat mempengaruhi yield BNC yang dihasilkan (Singhsa et al., 2018). Dalam penelitian ini strain bakteri dari industri nata sesuai untuk metode agitasi. Faktor terpenting selain komponen medium yang digunakan dan temperatur, keefektifan strain Gluconacetobacter dalam memproduksi selulosa adalah pasokan oksigen dan sumber karbon (seperti D-Glukosa) (Klemm et al., 2011). Glukosa adalah satu-satunya sakarida yang ditemukan dalam air kelapa yang disimpan dalam 3 hari. Dalam membuat nata de coco industri menambahkan gula sebanyak kurang lebih $1-2 \%$ dalam komposisi medium yang digunakan (Budhiono et al., 1999). Namun penambahan gula sebanyak $5 \%$ juga dapat meningkatkan pertumbuhan $A$. xylinum pada medium air kelapa (Indrianingsih et al., 2017). Selain dari air kelapa, A. xylinum juga dapat memproduksi selulosa dengan sumber glukosa dari buah nanas (Malvianie et al., 2014). Czaja et al. (2004) mengemukakan bahwa strain bakteri A. xylinum lebih efektif melakukan sintesa selulosa di dalam kultur agitasi.

Salah satu aplikasi BNC pada bidang farmasi adalah sebagai drugs delivery systems. Pötzinger et al., (2017) melaporkan bahwa BNC yang dihasilkan pada kultur agitasi dapat digunakan sebagai pembawa obat (drug carrier) dalam bentuk sediaan oral. Pengembangan BNC sebagai drugs delivery systems tergantung kepada kesedian biopolimer yang cukup dengan harga yang tejangkau (Muller et al., 2013). Sampai saat ini produksi BNC masih tinggi karena menggunakan medium yang mahal untuk mencapai rendeman tinggi sehingga dapat memenuhi kebutuhan selulosa dunia (Donini et al., 2010).

\section{Kesimpulan}

BNC yang diproduksi melalui perlakuan agitasi menghasilkan selulosa dengan berat basah 
dan berat kering lebih tinggi dibanding perlakuan statis. Isolat bakteri Gluconacetobacter sp. dengan kode JUM yang diperoleh dari industri nata de coco telah dipilih sebagai bakteri penghasil bacterial nanocellulose (BNC). Kondisi optimum isolat bakteri ini dalam menghasilkan selulosa terjadi pada kondisi $\mathrm{pH} 5,5$, suhu $27{ }^{\circ} \mathrm{C}$, dan kecepatan agitasi $150 \mathrm{rpm}$.

\section{Daftar Pustaka}

Atalla, R. H., \& Vanderhart, D. L. (1984). Native cellulose: a composite of two distinct crystalline forms. Science, 223, 283-285.

Benson, H. . (2001). Microbiological Application (8th ed.). Boston: The McGraw-Hill Companies.

Budhiono, A., Rosidi, B., Taher, H., \& Iguchi, M. (1999). Kinetic aspects of bacterial cellulose formation in nata-de-coco culture system. Carbohydrate Polymers, 40(2), 137-143. https://doi.org/10.1016/S01448617(99)00050-8

Castro, C., Zuluaga, R., Álvarez, C., Putaux, J. L., Caro, G., Rojas, O. J., Mondragon, I., \& Gañán, P. (2012). Bacterial cellulose produced by a new acid-resistant strain of Gluconacetobacter genus. Carbohydrate Polymers, 89(4), 1033-1037. https://doi. org/10.1016/j.carbpol.2012.03.045

Chen, G., Wu, G., Chen, L., Wang, W., Hong, F. F., \& Jönsson, L. J. (2019). Performance of nanocellulose-producing bacterial strains in static and agitated cultures with different starting pH. Carbohydrate Polymers, 215(February), 280-288. https://doi. org/10.1016/j.carbpol.2019.03.080

Coban, E. P., \& Biyik, H. (2011). Evaluation of different $\mathrm{pH}$ and temperatures for bacterial cellulose production in HS (HestrinScharmm) medium and beet molasses medium. African Journal of Microbiology Research, 5(9), 1037-1045. https://doi. org/10.5897/ajmr11.008

Czaja, W., Romanovicz, D., \& Brown, R. malcolm. (2004). Structural investigations of microbial cellulose produced in stationary and agitated culture. Cellulose, 11(3/4), 403-411. https:// doi.org/10.1023/b:cell.0000046412.11983.61

Dima, S. O., Panaitescu, D. M., Orban, C., Ghiurea, M., Doncea, S. M., Fierascu, R. C., Nistor, C. L., Alexandrescu, E., Nicolae, C. A., Trica, B., Moraru, A., \& Oancea, F. (2017). Bacterial nanocellulose from sidestreams of kombucha beverages production: Preparation and physical-chemical properties. Polymers, 9(8), 5-10. https://doi. org/10.3390/polym 9080374
Donini, Í. A. N., De Salvi, D. T. B., Fukumoto, F. K., Lustri, W. R., Barud, H. S., Marchetto, R., Messaddeq, Y., \& Ribeiro, S. J. L. (2010). Biossíntese e recentes avanços na produção de celulose bacteriana. Ecletica Quimica, 35(4), 165-178. https://doi.org/10.1590/ S0100-46702010000400021

Fu, L., Zhang, J., \& Yang, G. (2013). Present status and applications of bacterial cellulose-based materials for skin tissue repair. Carbohydrate Polymers, 92(2), 1432-1442. https://doi.org/10.1016/j. carbpol.2012.10.071

Gatenholm, P., \& Klemm, D. (2010). Bacterial nanocellulose as a renewable material for biomedical applications. MRS Bulletin, 35(3), 208-213. https://doi.org/10.1557/ mrs2010.653

Gayathry, G., \& Gopalaswamy, G. (2014). Production and characterisation of microbial cellulosic fibre from Acetobacter xylinum. Indian Journal of Fibre and Textile Research, 39(1), 93-96.

Gullo, M., Sola, A., Zanichelli, G., Montorsi, M., Messori, M., \& Giudici, P. (2017). Increased production of bacterial cellulose as starting point for scaled-up applications. Applied Microbiology and Biotechnology, 101(22), 8115-8127. https://doi.org/10.1007/ s00253-017-8539-3

Gupta, A., Briffa, S. M., Swingler, S., Gibson, H., Kannappan, V., Adamus, G., Kowalczuk, M., Martin, C., \& Radecka, I. (2020). Synthesis of Silver Nanoparticles Using CurcuminCyclodextrins Loaded into Bacterial Cellulose-Based Hydrogels for Wound Dressing Applications. Biomacromolecules, 21(5), 1802-1811. https://doi.org/10.1021/ acs.biomac.9b01724

Hu, Y., \& Catchmark, J. M. (2010). Formation and characterization of spherelike bacterial cellulose particles produced by acetobacter xylinum JCM 9730 strain. Biomacromolecules, 11(7), 1727-1734. https://doi.org/10.1021/bm100060v

Hutchens, S. A., León, R. V., O’Neill, H. M., \& Evans, B. R. (2008). Statistical analysis of optimal culture conditions for Gluconacetobacter hansenii cellulose production. Letters in Applied Microbiology, 44(2), 175-180. https://doi.org/10.1111/ j.1472-765X.2006.02055.x

Hwang, J. W., Yang, Y. K., Hwang, J. K., \& Pyun, Y. R. (1999). Effects of $\mathrm{pH}$ and Dissolved Oxygen on Cellulose Production by Acetobacter xylinum BRCS in Agitated Culture. JOurnal of Bioscience and Bioengineering, 88(2), 183-188. 
Indrianingsih, A., Rosyida, V., Jatmiko, T., Prasetyo, D. J., Peloengasih, C. D., Apriyana, W., Nisa, K., Nurhayati, S., Hernawan, H., Darsih, C., Pratiwi, D., Suwanto, A., \& Ratih, D. (2017). Preliminary study on biosynthesis and characterization of bacteria cellulose films from coconut wate. Iopscience.Iop. Org, 8(February 2018), 68-74. https:// doi.org/10.1088/1755-1315

Joseph, G., Rowe, G. E., Margaritis, A., \& Wan, W. (2003). Effects of polyacrylamideco-acrylic acid on cellulose production by Acetobacter xylinum. Journal of Chemical Technology and Biotechnology, 970(April), 964-970. https://doi. org/10.1002/jctb.869

Jozala, A. F., de Lencastre-Novaes, L. C., Lopes, A. M., de Carvalho Santos-Ebinuma, V., Mazzola, P. G., Pessoa-Jr, A., Grotto, D., Gerenutti, M., \& Chaud, M. V. (2016). Bacterial nanocellulose production and application: a 10-year overview. Applied Microbiology and Biotechnology, 100(5), 2063-2072. https://doi.org/10.1007/s00253015-7243-4

Jozala, A. F., Pértile, R. A. N., dos Santos, C. A., de Carvalho Santos-Ebinuma, V., Seckler, M. M., Gama, F. M., \& Pessoa, A. (2014). Bacterial cellulose production by Gluconacetobacter xylinus by employing alternative culture media. Applied Microbiology and Biotechnology, 99(3), 1181-1190. https://doi.org/10.1007/s00253014-6232-3

Klemm, D., Kramer, F., Moritz, S., Lindström, T., Ankerfors, M., Gray, D., \& Dorris, A. (2011). Nanocelluloses: A new family of nature-based materials. Angewandte Chemie - International Edition, 50(24), 5438-5466. https://doi.org/10.1002/ anie. 201001273

Klemm, D., Schumann, D., Udhardt, U., \& Marsch, S. (2001). Bacterial synthesized cellulose - Artificial blood vessels for microsurgery. Progress in Polymer Science (Oxford), 26(9), 1561-1603. https://doi. org/10.1016/S0079-6700(01)00021-1

Kost, J., Wiseman, D., \& Domb, A. J. (1998). Handbook of biodegradable polymers. CRC Press.

Kouda, T., Yano, H., \& Yoshinaga, F. (1997). Effect of agitator configuration on bacterial cellulose productivity in aerated and agitated culture. Journal of Fermentation and Bioengineering, 83(4), 371-376. https://doi. org/10.1016/S0922-338X(97)80144-4

M. Iguchi;, S. Yamanaka; \& A. Budhiono; (2000). Bacterial cellulose - a masterpiece of nature's arts. Journal of Materials Science, 35(2), 261-270. https://doi.org/10.1023/A
Malvianie, E., Pratama, Y., \& Salafudin, S. (2014). Fermentasi Sampah Buah Nanas menggunakan Sistem Kontinu dengan bantuan Bakteri Acetobacter Xylinum. Reka Lingkungan, 2(1), 1-11.

Mohammadkazemi, F. (2015). Surface Properties of Bacterial Nanocellulose Using Spectroscopic Methods and X-Ray Diffraction. American Journal of Applied and Industrial Chemistry, 1(2), 10-13. https://doi.org/10.11648/j.ajaic.20150102.11

Mohite, B. V., Salunke, B. K., \& Patil, S. V. (2013). Enhanced production of bacterial cellulose by using gluconacetobacter hansenii NCIM 2529 strain under shaking conditions. Applied Biochemistry and Biotechnology, 169(5), 1497-1511. https://doi.org/10.1007/ s12010-013-0092-7

Muller, A., NI, Z., Nadine, H., Wesarg, F., Muller, F. A., Kralisch, D., \& Fischer, D. (2013). The Biopolymer Bacterial Nanocellulose as Drug Delivery System: Investigation of Drug Loading and Release using the Model Protein Albumin. Journal of Pharmaceutical Sciences, 102(7), 579-592. https://doi.org/10.1002/jps

Nakagaito, A. N., Iwamoto, S., \& Yano, H. (2005). Bacterial cellulose: the ultimate nano-scalar cellulose morphology for the production of high-strength composites. Applied Physics A, 80(1), 93-97. https://doi.org/10.1007/ s00339-004-2932-3

Numata, Y., Sakata, T., Furukawa, H., \& Tajima, K. (2015). Bacterial cellulose gels with high mechanical strength. Materials Science and Engineering C, 47, 57-62. https://doi. org/10.1016/j.msec.2014.11.026

Pa'e, N., Zahan, K. A., \& Muhamad, I. I. (2011). Production of Biopolymer from Acetobacter xylinum Using Different Fermentation Methods. International Journal of Engineering \& Technology, IJETIJENS(October), 90-98.

Pandey, K. K. (1999). A study of chemical structure of soft and hardwood and wood polymers by FTIR spectroscopy. Journalof Applied Polymer Science, 71(12), 1969-1975. https://doi.org/10.1002/ (sici)1097-4628(19990321)71:12<1969::aidapp6>3.3.co;2-4

Pavaloiu, R. D., Stoica-Guzun, A., Stroescu, M., \& Dobre, T. (2014). Use of bacterial cellulose as reinforcement agent and as coating agent in drug release applications. Revista de Chimie, 65(7), 852-855.

Pötzinger, Y., Kralisch, D., \& Fischer, D. (2017). Bacterial nanocellulose: The future of controlled drug delivery? Therapeutic Delivery, 8(9), 753-761. https://doi. org/10.4155/tde-2017-0059 
Shoda, M., \& Sugano, Y. (2005). Recent Advance in Bacterial Cellulose Production. Biotechnology and Bioprocess Engineering, 10, 1-8.

Simanjuntak, R. (2016). Pengawasan Bahan Baku Obat Untuk Mendukung Kemandirian Bahan Baku Obat. In Seminar Pentahelix Kemandirian Bahan Baku Farmasi serta Lanching Information and Data Center. Jatinangor: Universitas Padjajaran.

Singhsa, P., Narain, R., \& Manuspiya, H. (2018). Physical structure variations of bacterial cellulose produced by different Komagataeibacter xylinus strains and carbon sources in static and agitated conditions. Cellulose, 25(3), 1571-1581. https://doi. org/10.1007/s10570-018-1699-1

Son, H.-J., Heo, M.-S., Kim, Y.-G., \& Lee, S.J. (2001). Optimization of fermentation conditions for the production of bacterial cellulose by a newly isolated Acetobacter sp.A9 in shaking cultures. Biotechnology and Applied Biochemistry, 33(1), 1. https:// doi.org/10.1042/ba20000065

Tanskul, S., Amornthatree, K., \& Jaturonlak, N. (2013). A new cellulose-producing bacterium, Rhodococcus sp. MI 2: Screening and optimization of culture conditions. Carbohydrate Polymers, 92(1), 421-428. https://doi.org/10.1016/j. carbpol.2012.09.017
Vandamme, E. J., De Baets, S., Vanbaelen, A., Joris, K., \& De Wulf, P. (1998). Improved production of bacterial cellulose and its application potential. Polymer Degradation and Stability, 59(1-3), 93-99. https://doi. org/10.1016/s0141-3910(97)00185-7

Watanabe, K., Tabuchi, M., Yasushi, M., \& Yoshinaga, F. (1998). Structural features and properties of bacterial cellulose produced in agitated culture. Cellulose, 5, 187-200.

Yue, Y., Han, J., Han, G., Zhang, Q., French, A. D., \& Wu, Q. (2015). Characterization of cellulose I/II hybrid fibers isolated from energycane bagasse during the delignification process: Morphology, crystallinity and percentage estimation. Carbohydrate Polymers, 133, 438-447. https://doi. org/10.1016/j.carbpol.2015.07.058

Zahan, K. A., Pa'e, N., \& Muhamad, I. I. (2015). Monitoring the Effect of $\mathrm{pH}$ on Bacterial Cellulose Production and Acetobacter xylinum 0416 Growth in a Rotary Discs Reactor. Arabian Journal for Science and Engineering, 40(7), 1881-1885. https://doi. org/10.1007/s13369-015-1712-z

Zywicka, A., Peitler, D., Rakoczy, R., Konopacki, M., Kordas, M., \& Fijałkowski, K. (2015). The Effect of Different Agitation Modes on Bacterial Cellulose Synthesis. Acta Sci. Pol. Zootechnica, 14(1), 137-150. 